\title{
Poor Study Skills and Untapped Resources: A Study of Entry-Level Mathematics Students' Study Habits
}

\author{
Annette Williams \\ University Studies, Middle Tennessee State University \\ PO Box 16, Murfreesboro, Tennessee 37132, United States \\ Tel: 1-615-898-5558_E-mail: annette.williams@mtsu.edu \\ Linda M. Clark \\ University Studies, Middle Tennessee State University \\ PO Box 16, Murfreesboro, Tennessee 37132, United States \\ Tel: 1-615-904-8234Ｅ-mail: linda.clark@mtsu.edu
}

Received: April 5, 2012

Accepted: April 22, 2012

Published: May 1, 2012

doi:10.5296/jse.v2i2.1601

URL: http://dx.doi.org/10.5296/jse.v2i2.1601

\begin{abstract}
The purpose of this descriptive study was to discover the environment in which students enrolled in entry and lower-level mathematics courses study, how long and when they study, whether they study in a group or alone, how they organize their notes and homework, and what use they make of the textbook and online class notes provided by their instructor. Fifty-eight students were interviewed in their instructors' offices. Responses were correlated to final grades in each course. Results indicated that students making higher grades studied earlier in the day and kept more organized notebooks than students who made lower grades. The majority of students studied alone and did not use the resources available to them.
\end{abstract}

Keywords: College students’ study habits, Entry level mathematics, Online homework 


\section{Introduction}

Students must spend adequate study time and meaningful effort to be successful in college. They are typically told they need to spend at least two hours studying or preparing for class for every hour spent in class. While there are many factors that contribute to successful performance in college courses, student study habits are seen as critically important to student success. Therefore, faculty teaching entry-level and underprepared mathematics students often find themselves strongly encouraging students to spend time studying outside the classroom to enhance their ability to learn the materials covered in class. According to the 2005 National Survey of Student Engagement (NSSE) report, high school seniors indicated that they expected to spend more time studying in college than they did in high school. Research indicates that students do indeed spend more time studying when they enter college than they did their senior year of high school. For example, McCarthy and Kuh, (2006) found that freshmen in four-year colleges spend twice as much time per week studying as high school seniors; however, the results of the NSSE of 2005 revealed that freshmen spent up to 6 hours less studying than they thought they would when starting college (Kuh, 2007). In fact, McCormick (2011) analyzing the data from NSSE reports from 2000 to 2010 noted that full-time NSSE respondents indicated that they, on average, spent one hour studying for every hour spent in class. It is clear that students may not study for as many hours as is typically suggested; however, the research does indicate that students do study.

A brief review of the literature on student study habits also revealed that many researchers (e.g., Treisman, 1992; Duncan \& Dick, 2000; Chin, Martin, \& Spencer, 2007) found that students were more successful when studying with others, particularly in courses requiring analysis or problem-solving skills. Indeed, in his research involving calculus students, Treisman (1992) noted that underachieving calculus students tended to study in isolation and rarely consulted with other students or used resources available to them. In contrast, he noted, higher-achieving students studied alone and with other students. As a result of his research, Treisman developed a workshop approach that required students to work informally in study groups. In their article, Duncan and Dick (2000) discuss implementing a Math Excel program for introductory college mathematics courses based on "the Treisman model" at their university. This program was not a requirement of the course and students volunteered to participate. Duncan and Dick reported that (after taking into consideration quantitative SAT-M scores) students involved in the program, over all courses, earned a 0.671 higher grade on a 4-point scale than students who were not involved in the program. While many of the researchers discussed formally structured workshops and programs to encourage group study, it is important to note that students who enrolled in the workshops are students who took advantage of the resources that were made available to them.

Along with considering the amount of time students spend studying, we wanted to determine how, when, where, and to some extent what they study? That is, when students spend time studying, what do they do with the time? Do they study alone or with others? What time of day do they study? And, do they study in a library, campus lab, or at home? This descriptive study was designed to investigate the study habits of students in entry-level, transitional 
mathematics courses, and as such, does not attempt to address other important issues associated with students successfully completing courses.

\section{Methods}

A convenient sample of students, those enrolled in the investigators' entry-level mathematics courses, participated in the study. Four sections in the fall of 2008, one section in the spring of 2009, and one section in the spring of 2010 were chosen. Four sections were Essentials of Mathematics, a prescribed course for students having low ACT scores. Two sections were Transitional College Algebra, a transitional, general education mathematics course designed for students having slightly higher ACT scores than the students identified to take the Essentials of Mathematics course. The students were enrolled at a large southeastern university.

The fall 2008 cadre of students completed a study journal each day in class for three weeks and completed an interview with their instructor. The students enrolled in the sections taught during the spring semesters only completed interviews. After the first semester, the journal was not used because it did not prove as useful as the interviews for the purpose of the study. In the study journal, students recorded the amounts of time spent since the last class meeting studying in various ways such as completing online homework, reading the textbook, and watching video lectures. The interviews were conducted in the instructors' offices. Students were asked21questions (see Appendix) related to how and where they studied and what resources they used such as tutors, textbooks, online notes, and study groups. The students were also asked to estimate the amount of time they spent each week studying. During the interviews the instructors also evaluated each student's notebook.

As an incentive for completing the interview, students were rewarded a few extra points added to one test grade. The interview process had the added benefit of allowing one-on-one contact with many students who otherwise would not have come to a faculty office. Though it was not the purpose of this study to track retention, it certainly can be affected with this type of engagement with the professor (Tinto, 1993; Graunke \& Woosley, 2005).

The study included 68 student journals and 58 interviews. Data from the interviews and the study journals were compiled correlating to final grades in the course. Student grades were A, B, C, and F. No D grade was allowed for either course. For the interview data, the distribution of final grades for A, B, C, and F was 15, 23, 14, and 6, respectively.

\section{Course Background}

Transitional College Algebra meets four hours per week and includes topics from intermediate algebra as well as all of the topics in the regular, three-hour College Algebra course. The three-hour Essentials of Mathematics course includes topics from algebra, problem solving skills, and technology use. Both courses use Pearson Addison Wesley Course Compass courseware with online resources including textbook, homework, video lectures, communication, and more. The homework component, known as My Math Lab (MML), gives students examples to follow and step-by-step directions for solving problems. After three unsuccessful attempts to solve a problem, the student is given the solution and 
allowed to try another similar problem. All homework is automatically graded and recorded in the online grade book. Offline items, such as tests or project grades can be uploaded. Grades can be weighted so that a student can see his or her current grade average at any time. Tests were not given online, but the grades were uploaded. Findings of studies exploring the effects of online homework vary. For example, Kodippiland Senaratne (2008) found 70\% of students using MML succeeded (A, B,C for a final grade) compared to $49 \%$ using traditional homework. On the other hand, Jacobson (2006) found computer homework did not help students learn; however, the computer homework in this study was only used for " $25 \%$ (10 out of 39) non-exam class meetings of the semester” (p. 3). Students in Jacobson's study may not have had enough time to become proficient with the software. From our seven years of experience with MML, we have learned that students need about two weeks to become accustomed to the software. Anecdotally, our students report a preference for the online homework over the traditional pencil-and-paper assignments and an appreciation of the immediately available tutorial assistance with each exercise.

Students in these courses have access to a departmental math lab that is open 40 hours per week and is staffed with faculty and student tutors. The math lab has 27 computers for student use and adaptive technology for visually impaired students. Other computer labs are available to students including those in residence halls, classroom buildings, a learning resource center, and the library.

\section{Results}

The results from several of the interview questions stood out. For example, 66\% studied at their residence only (see Table 1 ) and 67\% studied in a quiet environment. Also, it is clear that the majority of students studied in isolation since $72 \%$ always studied alone.

Table 1. Study Locale and Final Grade

\begin{tabular}{lccccccccccc}
\hline & & & & & & & & & & \\
& A & & B & & C & & F & \multicolumn{3}{c}{ Total } & \\
\cline { 2 - 11 } Where do you study? & $n$ & $\%$ & $n$ & $\%$ & $n$ & $\%$ & $n$ & $\%$ & $n$ & $\%$ \\
\hline Residence & 10 & 67 & 18 & 78 & 6 & 43 & 4 & 67 & 38 & 66 \\
Residence/Other* & 3 & 20 & 1 & 4 & 7 & 50 & 0 & 0 & 11 & 19 \\
Not Residence & 2 & 13 & 4 & 17 & 1 & 7 & 2 & 33 & 9 & 16 \\
Total & 15 & 26 & 23 & 38 & 14 & 24 & 6 & 10 & 58 & 100 \\
\hline
\end{tabular}

*Residence/Other indicates student used a combination of residence and labs. 
Furthermore, with 55\% never using the math lab tutors (see Table 2), 76\% never using other tutors (see Table 3), and 55\% never reading the textbook, they certainly did not utilize the available resources. These were fairly consistent findings regardless of the final grade.

Table 2. Math Lab Visits and Final Grade

\begin{tabular}{lccccccccccc} 
& A & \multicolumn{1}{c}{ B } & & $\mathrm{C}$ & & $\mathrm{F}$ & \multicolumn{3}{c}{ Total } \\
\cline { 2 - 10 } & $n$ & $\%$ & $n$ & $\%$ & $n$ & $\%$ & $n$ & $\%$ & $n$ & $\%$ \\
\hline Often & 1 & 7 & 4 & 17 & 4 & 29 & 1 & 17 & 10 & 17 \\
Occasionally & 1 & 7 & 0 & 0 & 2 & 14 & 1 & 17 & 4 & 7 \\
Rarely & 4 & 27 & 3 & 13 & 3 & 21 & 2 & 33 & 12 & 21 \\
& & & 1 & & & & & & & \\
Never & 9 & 60 & 6 & 70 & 5 & 36 & 2 & 33 & 32 & 55 \\
& & & 2 & & & & & & & \\
Total & 15 & 26 & 3 & 38 & 14 & 24 & 6 & 10 & 58 & 100 \\
\hline
\end{tabular}

It is also important to note that in addition to the tutors that are available in the previously mentioned math lab, there are tutors available in many of the residence halls on campus, for students participating in special programs (e.g., TRIO), and for athletes.

Table 3. Use of other Tutoring Services and Final Grade

\begin{tabular}{lccccccccccc}
\hline $\begin{array}{l}\text { How often do you use other } \\
\text { tutors? }\end{array}$ & A & \multicolumn{1}{c}{ B } & & C & & F & & Total \\
\cline { 2 - 10 } & $n$ & $\%$ & $n$ & $\%$ & $n$ & $\%$ & $n$ & $\%$ & $n$ & $\%$ \\
\hline Often & 0 & 0 & 2 & 9 & 1 & 7 & 0 & 0 & 3 & 5 \\
Rarely & 2 & 13 & 4 & 17 & 5 & 36 & 0 & 0 & 11 & 19 \\
& 13 & 87 & 7 & 74 & 8 & 57 & 6 & 100 & 44 & 76 \\
Never & & & 2 & & & & & & & \\
Total & 15 & 26 & 3 & 38 & 14 & 24 & 6 & 10 & 58 & 100 \\
\hline
\end{tabular}

Ninety-five percent of all students reported that they usually did all of their online homework (A-100\%, B-96\%, C-93\%, and F-83\%). These claims were verified by checking the online homework grades. Students reported studying an average of 4.1, 4.8, 5.1, and 5.1 hours per week for grades of A, B, C, and F, respectively (see Table 4).Interestingly, for the students 
who completed the study journals the average study time reported was 4.6 hours as compared to 4.7 hours for the interviews.

Table 4. Time Studying and Final Grade

\begin{tabular}{|c|c|c|c|c|c|c|c|c|c|c|}
\hline \multirow{2}{*}{$\begin{array}{l}\text { How much time do } \\
\text { you study per week? }\end{array}$} & \multicolumn{2}{|l|}{ A } & \multicolumn{2}{|l|}{$\mathrm{B}$} & \multicolumn{2}{|l|}{$\mathrm{C}$} & \multicolumn{2}{|l|}{$\mathrm{F}$} & \multicolumn{2}{|c|}{ Total } \\
\hline & $n$ & $\%$ & $n$ & $\%$ & $n$ & $\%$ & $n$ & $\%$ & $n$ & $\%$ \\
\hline $1-2.9$ & 3 & 20 & 4 & 17 & 2 & 14 & 2 & 33 & 11 & 19 \\
\hline $3-4.9$ & 8 & 53 & 10 & 43 & 5 & 36 & 1 & 17 & 24 & 41 \\
\hline $5-6.9$ & 3 & 20 & 3 & 13 & 5 & 36 & 1 & 17 & 12 & 21 \\
\hline 7-9.9 & 0 & 0 & 5 & 22 & 1 & 7 & 2 & 33 & 8 & 14 \\
\hline $10-13$ & 1 & 7 & 1 & 4 & 1 & 7 & 0 & 0 & 3 & 5 \\
\hline $\begin{array}{l}\text { Average Hours } \\
\text { Studied per Week }\end{array}$ & 4.1 & & 4.8 & & $\begin{array}{r}5 . \\
1\end{array}$ & & 5.1 & & 4.7 & \\
\hline
\end{tabular}

There were areas where the higher- and lower-achieving student groups differed. The greatest differences were noted in the time of day they studied and in the type of notebooks they kept. Students earning an A reported studying predominantly in the afternoon, 40\%, with only $7 \%$ (1 student) reporting studying late (after 9:00 PM). However, of those making an F,67\% reported predominantly studying late. Table 5 shows that the percentage of students studying latein creased as the grades dropped: A-7\%, B-13\%, C-21\%, and F-67\%.

Table 5. Typical Time of Study and Final Grade

\begin{tabular}{lccccccccccc} 
What time of day do & A & \multicolumn{1}{c}{ B } & & $\mathrm{C}$ & \multicolumn{1}{c}{$\mathrm{F}$} & \multicolumn{3}{c}{ Total } \\
\cline { 2 - 10 } you study? & $n$ & $\%$ & $n$ & $\%$ & $n$ & $\%$ & $n$ & $\%$ & $n$ & $\%$ \\
\hline Morning & 2 & 13 & 2 & 9 & 0 & 0 & 0 & 0 & 4 & 7 \\
Afternoon & 6 & 40 & 3 & 13 & 2 & 14 & 1 & 17 & 12 & 21 \\
Early evening & 3 & 20 & 8 & 35 & 5 & 36 & 1 & 17 & 17 & 29 \\
Night & 1 & 7 & 3 & 13 & 3 & 21 & 4 & 67 & 11 & 19 \\
Different times & 3 & 20 & 7 & 30 & 4 & 29 & 0 & 0 & 14 & 24 \\
\hline
\end{tabular}


When notebooks were checked, $57 \%$ of the students with an A and $35 \%$ with a B had well-organized, complete notebooks, while none of the students with an F had such (see Table 6). Interestingly, $98 \%$ of the students said that they took notes in class.

Table 6. Notebook Organization and Final Grade

\begin{tabular}{|c|c|c|c|c|c|c|c|c|c|c|}
\hline \multirow{2}{*}{ Show me your note book. } & \multicolumn{2}{|l|}{ A } & \multicolumn{2}{|c|}{$\mathrm{B}$} & \multicolumn{2}{|l|}{$\mathrm{C}$} & \multicolumn{2}{|l|}{$\mathrm{F}$} & \multicolumn{2}{|c|}{ Total* } \\
\hline & $n$ & $\%$ & $n$ & $\%$ & $n$ & $\%$ & $n$ & $\%$ & $n$ & $\%$ \\
\hline Good/Well-organized & 8 & 57 & 8 & 35 & 3 & 21 & 0 & 0 & 19 & 33 \\
\hline Mediocre & 3 & 21 & $\begin{array}{l}1 \\
0\end{array}$ & 43 & 7 & 50 & 3 & 50 & 23 & 40 \\
\hline Bad/Nonexistent & 3 & 21 & 5 & 22 & 4 & 29 & 3 & 50 & 15 & 26 \\
\hline
\end{tabular}

*One student did not show a notebook at the interview.

Students in all sections had access to instructor created class notes that are designed to facilitate taking structured notes in class. At least $60 \%$ of students with an A, B, or C reported that they often printed notes from the instructors' Websites, while only $33 \%$ of the students earning an F did so (see Table 7).

Table 7. Use of Instructor’s Class Notes and Final Grade

\begin{tabular}{lccccccccccc}
\hline \multirow{2}{*}{$\begin{array}{l}\text { Do you print copies of } \\
\text { my notes from my }\end{array}$} & $\mathrm{A}$ & \multicolumn{1}{c}{ B } & & $\mathrm{C}$ & & $\mathrm{F}$ & \multicolumn{3}{c}{ Total } \\
\cline { 2 - 10 } Website? & $n$ & $\%$ & $n$ & $\%$ & $n$ & $\%$ & $n$ & $\%$ & $n$ & $\%$ \\
\hline Often/yes & 9 & 60 & 14 & 61 & 9 & 64 & 2 & 33 & 34 & 59 \\
Occasionally & 1 & 7 & 2 & 9 & 1 & 7 & 0 & 0 & 4 & 4 \\
Rarely & 2 & 13 & 5 & 22 & 1 & 7 & 1 & 17 & 9 & 16 \\
Never & 3 & 20 & 2 & 9 & 3 & 21 & 3 & 50 & 11 & 19 \\
\hline
\end{tabular}


From Table 8 we see that the students earning A, B, and C, 29-40\% reported often keeping the worked problems from their online homework in a notebook; and of the students earning an $\mathrm{F}$, none did so.

Table 8. Maintenance of Homework Log and Final Grade

\begin{tabular}{|c|c|c|c|c|c|c|c|c|c|c|}
\hline \multirow{2}{*}{$\begin{array}{l}\text { Do you keep work from } \\
\text { each problem of your } \\
\text { homework in a } \\
\text { notebook? }\end{array}$} & \multicolumn{2}{|l|}{ A } & \multicolumn{2}{|l|}{$\mathrm{B}$} & \multicolumn{2}{|l|}{$\mathrm{C}$} & \multicolumn{2}{|l|}{$\mathrm{F}$} & \multicolumn{2}{|l|}{ Total } \\
\hline & $n$ & $\%$ & $n$ & $\%$ & $n$ & $\%$ & $n$ & $\%$ & $n$ & $\%$ \\
\hline Often/yes & 6 & 40 & 8 & 35 & 4 & 29 & 0 & 0 & 18 & 31 \\
\hline Occasionally & 2 & 13 & 4 & 17 & 1 & 7 & 1 & 17 & 8 & 14 \\
\hline Rarely & 2 & 13 & 0 & 0 & 0 & 0 & 0 & 0 & 2 & 3 \\
\hline Never & 5 & 33 & 11 & 48 & 9 & 64 & 5 & 83 & 30 & 52 \\
\hline
\end{tabular}

\section{Discussion}

Students' study time was primarily spent completing online homework assignments. They generally completed the assignments. This could be because the assignments were all assessed and weighted at $15 \%$ of the students' final grades. Cerrito and Levi (1999) found regular collection of homework correlated with increased study time. There was little indication that our students studied beyond homework completion and test preparation. Only 4 students indicated other uses for notes, such as preparing for class or reworking problems in the notes. Students earning higher grades (A and B) studied earlier in the day and kept more complete, better-organized notebooks than students earning lower grades ( $\mathrm{C}$ and $\mathrm{F}$ ) in the course. Of the students who failed, only 1 out of the 4 reported ever keeping a copy of any homework problems, and not one of them had a well-organized notebook. This indicates a need for teaching general study skills. Interestingly, there was an inverse relationship between the reported amount of study time and grades. Whether this could be attributed to academic background or other factors is a topic for further study. Anecdotally, several students during the interviews admitted that they put off studying math, choosing to study other subjects first, because they did not do well in math or did not like math.

It was determined that the students made little or no use of the resources available to them beyond completing the online homework. They rarely used the textbooks that were available to them online, nor did they use the free tutoring available on campus. Students need encouragement and incentive to visit the math lab and use the tutoring services. We are making more specific assignments of lab time to encourage them to take that first step 
through the door. After using the lab, most comments are very positive; they acknowledge the benefits of the tutoring.

Many students struggle with anxiety, poor performance, and self-doubt in mathematics courses throughout elementary and high school (Wigfield \& Meece, 1988). Students in our study predominantly studied alone at their residences as has been found in other research (Kuo, Hagie, \& Miller, 2004). This isolation certainly does not help them to overcome the lack of self-efficacy nor the lack of self-regulation in college students that has been documented in other research (Hall \& Ponton, 2005; Young \& Ley, 2000).

\section{Conclusion}

The primary use of this study for us is being able to share with our students the characteristics of a successful student: keeping a well-organized notebook (inclusive of good class notes and copies of submitted homework problems) and studying earlier in the day. Furthermore, since we believe students would benefit from using the available resources and employing study strategies that include both time studying alone and with others, we encourage students to work together by assigning group projects. We also found, anecdotally, that interviewing students proved to be not only an effective way to begin investigating student study habits but also to be a tool to build relationships overcoming some of that isolation. Therefore, we are making a greater effort to spend time outside of class with students, particularly those who are struggling or repeating a course. Willingness to spend time with students lets them know that you care.

\section{Limitations and Directions for Further Research}

As previously mentioned this study was designed with multiple limitations. As a descriptive study, it does not provide a comparison of statistical differences between students' study behaviors. A more quantitative study with statistical comparisons that would allow for the investigation of what, if any, effects the variables in the study have on final grades in the course. Secondly, sampling in this study was limited to students in two courses. Future research should include a larger sample of students as well as student demographics to provide for broader generalization. However, even with the limitations this study provides a basis for encouraging students to be well-organized, be mindful of the time and location in which they study, and use the resources available to enhance opportunities for successful completion of entry-level mathematics courses.

\section{References}

Cerrito, P. B., \& Levi, I. (1999).An investigation of student habits in mathematics courses. College Student Journal, 33(4), 584-590.

Chinn, D., Martin, K., \& Spencer, C. (2007). Treisman workshops and student performance in CS.SIGCSE Bulletin, 39(3), 203-207. http://dx.doi.org/10.1145/1227504.1227383

Duncan, H.,\& Dick, T. (2000). Collaborative workshops and student academic performance in introductory college mathematics courses: A study of a Treisman model math excel 
program. School Science and Mathematics, 100(7), 365-373. http://dx.doi.org/10.1111/j.1949-8594.2000.tb18178.x

Graunke, S., \& Woosley, S. (2005).An exploration of the factors that affect the academic success of college sophomores.College Student Journal, 39(2), 367-376.

Hall, J. M., \& Ponton. M. K. (2005). Mathematics self-efficacy of college freshmen. Journal of Developmental Education, 28(3), 26-33.

Jacobson, E. (2006). Computer homework effectiveness in developmental mathematics.Journal of Developmental Education, 29(3), 2-4, 6-8.

Kuh, G. D. (2007). What student engagement data tell us about college readiness. Peer Review,9(1) 4-8.

Kuo, J., Hagie, C., \& Miller, M. T. (2004). Encouraging college student success: The instructional challenges, response strategies, and study skills of contemporary undergraduates. Journal of Instructional Psychology, 31(1), 60-67.

Kodippil, A., \& Senaratne, D. (2008). Is computer-generated interactive mathematics homework more effective than traditional instructor-graded homework? British Journal of Educational Technology, $\quad 39(5), \quad 928-932$. http://dx.doi.org/10.1111/j.1467-8535.2007.00794.x

McCarthy, M., \& Kuh, G. (2006). Are students ready for college? What student engagement data say. Phi Delta Kappan, 87(9), 664-669.

McCormick, A.C. (2011). It's about time: What to make of reported declines in how much students study. Liberal Education, 97(1), 30-39.

National Survey of Student Engagement (NSSE). 2005. Student engagement: Exploring different dimensions of student engagement. Bloomington, IN: Indiana University Center for Postsecondary Research. http://nsse.iub.edu/NSSE_2005_Annual_Report/

Tinto, V. (1993). Leaving college: Rethinking the causes and cures of student attrition. Chicago and London: The University of Chicago Press.

Treisman, U. (1992). Studying students studying calculus: A look at the lives of minority mathematics students in college. The College Mathematics Journal,23(5), 362-372. http://dx.doi.org/10.2307/2686410

Wigfield, A., \&Meece, J. (1988). Math anxiety is elementary and secondary school students. $\begin{array}{llll}\text { Journal of } & \text { Educational } & \text { Psychology. }\end{array}$ http://dx.doi.org/10.1037/0022-0663.80.2.210

Young, D. B., \& Ley, K. (2000). Developmental students don't know that they don't know part1: Self- regulation. Journal of College Reading and Learning, 31(1), 54-59.

\section{Appendix I}

Interview Questions for Study on Student Study Habits 
1. Where do you usually study?

2. Do you study in a quiet environment?

3. What time of day do you usually study?

4. How many times per week do you study and for how long each time?

5. Do you study with another student or group of students?

6. How often do you use the tutors in the Math Lab?

7. How often do you use other tutors? Who provides them?

8. Do you usually do your online homework at home, on campus in the Math Lab, or on campus at another lab?

9. Do you usually complete all of your online homework?

10. Do you review or rework the online problems?

11. Do you keep your work from each problem of the homework in a notebook?

12. Do you print a copy of the online homework problems?

13. Do you read the textbook material? If so, how often?

14. Do you have a hard copy of the textbook?

15. Do you ever print parts of the online textbook?

16. Do you work extra problems from the textbook?

17. Do you take notes in class?

18. Do you print copies of my notes from my Website?

19. How do you use the class notes?

20. Show me your notebook and explain how you organize and use it?

21. What other ways do you study that we have not discussed so far? 